\title{
ECONOMIC ESSENCE AND COMPONENTS OF FINANCIAL SUPPORT OF AGRICULTURAL SECTOR
}

\author{
Volodymyr MATSKIV ${ }^{1}$, \\ Vasyl Stefanyk Precarpathian National University, Ukraine
}

\begin{abstract}
The purpose of the paper is scientific grounding of theoretical and methodological approaches to the fundamental principles of the functioning of the existing system of financial support of the agrarian sector in Ukraine and its potential areas of its improvement through the construction of new effective financing mechanisms. Methodology. In the study the following methods are used: a comparative and morphological methods - to reveal the content and development of scientific thoughts about the interpretation of the concept of «financial support»; methods of systematization and generalization - to determine the functionality of the agricultural sector and the need of its financial support and to reveal the features of its functioning; systemic method - to construct a model of the implementation of agricultural sector financial support; logical method - for a consistent generalization of theoretical and practical scientific research statements. Results. Investigation of formation and development of the doctrine of financial support and systematization of scientific thoughts about its essence gives the opportunity to consider the content of the studied category in terms of the functional approach. Interpretation of the term "financial support" comes down to the statement that the formation of the theoretical foundations of the essence and the economic nature of financial support is a result of the achievements of several generations of scientists, each of whom invested a significant contribution to the development of the theory of the studied concept. This allowed us to analyze the term «financial providing» and to summarize the existing approaches in the light of the activities of the agricultural sector. In terms of functionality we found that financial support as a phenomenon can be seen in the context of its unique significance in the development of the economy. Practical implications. It was determined that the problems of financial support of the agricultural sector in Ukraine have a complex nature and relate to the economic, social and political spheres of its operation. The most important obstacles in the financial and credit sphere were and remain as follows: lack of adequate financial infrastructure to facilitate its development; lack of property that can be taken as sufficiently liquid collateral to guarantee repayment of the loan; complicated procedure for obtaining a bank loan and the length of the decision-making on the provision of concessional loans; lack of common rules for access of entities to the sources of financial resources; systematic need for funds for working capital; need for financial resources for the operation etc. In the article it is concretized and enhanced the concept of «financial security» as a system, which is characterized by a set of elements (tools, forms, methods of financing, leverages of the financial impact) and the relationship between them, the proper organization of which should focus on the effective development of the agricultural sector, and the fulfillment of its functions and the ability to show the closeness of the relationship between all the structural elements of the system in the process providing of agrarian business by financial resources. Value/originality. Such interpretation of the essence of «financial support» allows making justification of funds of financial support of the agricultural sector of Ukraine.
\end{abstract}

Key words: financial support, financial mechanism, agricultural sector, financial provision, funding sources.

JEL Classification: G10, G28, Q10

\section{Introduction}

During the period of overcoming the crisis trends in national economy development, the threat of loss of various types of economic security increases. Among them food safety plays a special role, a key component of which is the production of basic food products in required quantities in the country. It requires providing the domestic agribusiness primarily with financial resources. An important task at this stage is to create the conditions for economic stabilization and further development of agricultural production, strengthening the role of the financial mechanism witch best meets the conditions of business environment and management and allows us to redirect the system of state support to increasing the efficiency of agriculture.

\footnotetext{
Corresponding author:

${ }^{1}$ Department of Finance, Vasyl Stefanyk Precarpathian National University.

E-mail: Gy40k@mail.ru
} 
Under the conditions of market reforms and economic stabilization in Ukraine one of the basic tools of revitalization of the agricultural sector is to create a proper financial support for its development, which caused by the determining role of the studied subjects in social and economic recovery of the country. The experience of highly developed countries in formation and development of agricultural business shows that its effective functioning occurs in a complex of financial support conditions and establishment of mutually beneficial partnerships between business entities, state, and active subjects of the financial infrastructure.

Formation of the system of financial support of the agricultural sector in Ukraine is still going on. However, in the context of budgetary constraints, the instability of the state policy in the field of financial support for agricultural producers and encouraging alternative forms of funding, lack of effective mechanisms of financial and credit support is accompanied by a high level of financial risks. That is why tangible positive results have not been achieved. Likewise socioeconomic status of studied subjects has not been transformed neither in the direction of serious quantitative increase of their activity efficiency, nor in terms of quality parameters of development.

\section{The interpretation of the essence of $\ll$ financial security $\gg$}

The term «support» refers to «a set of measures and tools, creation of conditions that promote the implementation of plans, programs, projects and maintenance of stable system operation». Therefore, the object of financial support of the enterprise is the processes of simple and expanded reproduction.

Modern interpretation treats «support» in the diverse value (Kuznetsov, 1998). It is identified several important scientific economic research provisions. The considered concept is presented as a combination of cash or tangible assets. These elements are supporting the existence of economic and social actors. As support a number of actions can be considered, such as holding a set of actions or the adoption of the list of measures (Bodi, 2013).

The essence of financial support as a financial category should be based on the economic substance of finance and its functions. Finance performs not only distribution and control functions, but also a function of generating cash income. This allows logical assuming the mandatory signification of these functions in the process of financial support. Indeed, a support function is shown, for example, in the financing of infrastructure in the process of funds formation for financing the implementation of infrastructure projects.

However, it is not enough for clarification of the financial support essence. Financial support is closely connected with forms and methods of such a support. This relationship has stable and systematic character. Therefore, financial support represents a system of comprehensive selection of the most appropriate and sufficient sources of funds and institutional forms of financial control of their attraction for development of the agricultural sector.

S. V. Barulin presents financial support as a twoway process (Barulin, 2010). Ambiguity considers the sub-process of formation of financial resources and, accordingly, their use. It is noted the importance of each of the sub-processes and their direct dependence and interdependence. The author maintains the processing contents of financial support. Moreover, providing support for real production and social sector is realized through the financial support in the aspect of social reproduction and fulfilling needs of citizens.

Financial support is also treated as a capital management. In the extended aspect financial support is presented as efforts of attracting, usage and allocation of capital. A positive side of considered approach is processing contents of financial support and need for sound management decisions. In economic literature there are various options for determining the term «financial support $\gg$.

I. V. Zyatkovskyy gives the interpretation of the term «financial support» as follows: «Financial support is a system of sources and forms of financing the development of the economic and social spheres of society». One may agree with his opinion that it is carried out in three forms: self-financing, loans, budget allocations (Zyatkovskyy, 2000).

According to T. V. Sokolska, agriculture is a unique industry in Ukraine, one of the few which recently demonstrates growth in the current economic conditions of the optimum financial security, which is understood as providing business entities with fixed and circulating assets, own and borrowed financial resources, sufficient for the release of the planned volume of production. Financial support provides the continuity of the production and sale of agricultural products and minimizes costs. However, current government policy in this regard is haphazard, inefficient and unable to meet the needs of the subjects of agricultural production (Sokolsky, 2014). In general, the term «financial support of the agriculture materialtechnical base reproduction $\gg$ should be understood as a set of methods, techniques and tools of economic influence, which is held by public authorities and market structures, aimed at reproductive processes in the agricultural sector, including the renewal of the material technical resources.

The whole range of funding sources for fix assets renewal in agricultural sector can be conditionally divided into three groups:

1) funds generated by enterprises on their own on the basis of productive work;

2) funds received by farmers from the outside.

Analysis and systematization of the positions of the various authors allows us to single out two basic approaches to understanding the essence of financial support. Some economists such as N. L. Kardanskaya (Kardanskaya, 1999), A. M. Babich (Babich, Pavlova, 1999), and others treat it as a capital management process. While others, 
such as N. F. Samsonov (Samsonov, 2001), S. V. Bolshakov (Bolshakov, 2006), and others define it as the process of support the enterprise with financial resources. Given that the formation and flows of capital are implemented by attracting and allocating financial resources, we believe that the concept of financial support may be reduced to financial management. This is supported also by the fact that the movement of financial resources may be significantly wider than movement of capital, for instance, when temporarily free funds are used in the financial market or provided in the form of loans to other economic operators. L. N. Pavlova interprets financial support as a set of forms and methods, principles and terms of financing businesses.. Financial support for entrepreneurship is a capital management, activities of its attraction, development and use (Pavlova, 2003). Organizational and economic mechanism of agricultural enterprises financial support is a system of elements of organization, search and mobilization of financial resources and corresponding economic instruments, that can help to achieve the main goal - revenue of necessary financial resources for the agricultural production providing (Andriichuk, 2004). T. V. Shablovskaya defines financial support as a process of formation, distribution (placement) and further use of the part of financial resources such as entity capital, aimed at achieving the goal, which is the subject of financial management and controlled by the elements of the financial mechanism (Shablovskaya, 2007). P. A. Stetsiuk ascertained that the problem of financial support at the micro level is not in a lack of financial resources in general, but in access to them of a particular company and in forms and methods of their distribution between economic sectors and economic entities (Stetsiuk, 2005). V. M. Oparin, says: «... financial support is realized on the basis of an appropriate system of financing, which may be carried out in three forms: self-financing, loans, external funding. Various forms of financial support are used in practice simultaneously through the establishment of the optimal relationship between them for a given stage of development of society... » (Oparin, 2001). After all, as L. V. Dikan and Yu. Holub say: «... the meaning of the term «financial support of the enterprise activity» in a broader sense summarizes a set of measures and conditions that promote sustainable development of the enterprise through covering the costs by financial resources depending on the size of production and financial situation ...» (Dikan, Holub, 2007). That means the first place in this definition is taken by a set of events and conditions that make possible to ensure the financial activities of the company. A. E. Hutz is considering financial support as a possibility of economic entity to provide its own activities by necessary financial resources (Hutz, 2007). V. M. Rodionova determines the financial support of the reproduction process as a «covering of reproduction costs by financial resources accumulated by business entities and state» (Rodionova, 1994). Thus, according to supporters of this approach, financial support is the process of attracting and accumulating financial resources by business entities and the state for their further use in order to cover costs and targeted funding.

In most scientific sources, financial support is offered to assume as part of the financial management system, aimed at transformation of financial resources into capital in monetary form by attracting funds and their use for certain activity purposes, which is based on such a financial method as financing, and operation regulator- elements of the financial mechanism.

Generalization of theoretical bases of financial support shows the relationship between the overall economic approaches to the process of ensure and basic principles of finance category. In terms of economic activities and legislative definition it is determined a direct relationship between financial support and cash flow. In the scale of the system in the agricultural sector it has being established the interaction between the process of funds formation and use and progress of the state guarantees execution in the process of determining the composition, structure and amount of funding.

\section{Objectives and mechanisms of financial support of agricultural sector}

Financial support of production processes in the agricultural sector, which is one of the important channels of cash flows, characterizes the ability of the financial system to generate such economic relations between the subjects of the reproduction process about the movement of financial resources which will provide the economic development that is needed for national economic security, performing the country's role as one of the global leaders in food production, and meeting the needs in the bioenergy resources and the socio-economic needs of society.

There are two main goals of financial support:

1. Coverage of current needs.

2. Implementation of capital costs.

Effective formation and implementation of the financial support system is only possible if it will be build a rational system of its organizational support. The organizational mechanism component of financial resources formation in agricultural sector is formed by relevant actors of state financial system. Agriculture in Ukraine is a sector of the national economy, which brings together different types of economic activities in the production of agricultural products, food products, as well as their delivery to the final consumer. In the agricultural sector it is generated about $17 \%$ of GDP. It is one of the main budget making and export oriented sectors of national economy, which determines the practical importance and relevance of investigation of financial support problems of the enterprises (Goncharov, Ivanyuk, 2012).

Under such conditions, it becomes apparent that the further development of the sector requires qualitative transformations, capable to increase the competitiveness of agricultural production and food security of the state, the economic development of the agricultural sector. 
As international experience shows, the government should create effective ways to solve the problem of full financial support to agriculture by setting clear strategic orientations of its development, according to which state policy will be carried out in the directions of legal, financial and other economic regulation of the industry (Lupenko, MeselVeseliak, 2012).

The financial support effectiveness of the financial agroindustrial complex functioning is primarily determined by the optimal structure and content of the financial mechanism of the agricultural sector, which has significant industry specificity, which is typical only to this sector of the economy. To assess the quality of agricultural enterprises financial support in relation to the financial mechanism of the agricultural sector in the first place should be allocated four of its main elements that are the most adapted for use in agriculture:

1) financial planning, made by using program-oriented method, project method, and the method of expert evaluations;

2) financial support, carried out by buying, financing, lending and investing;

3) regulation, realized by the tax and customs policy, licensing, quotas and certification;

4) financial control, carried out within the framework of audit, inspection, evaluation, monitoring and analysis.

\section{Results}

The mechanism of financial support of business processes is understood as a specific set of resources, states and processes which determine the procedure for approval of the financial, economic and institutional relations on the formation and use of financial resources in order to achieve continuous production cycles, through the formation of a balanced system meet the capital needs of active economic systems. The structure of the financial mechanism of the production process contains two databases:

- functional, the system of financing productive activities, reflecting the contour and of financial resources flow shape (accumulation and distribution) in the process of meeting the needs of business entities the capital - financing in the narrow sense;

- institutional, revealing the movement patterns of financial and resource flows - financing system of business activity as a set of mediating financing of productions relations processes and institutions in the economy, the leading of which is the state that regulates the formation and use of investment resources, forming the regulatory, legal, information and analytical support - capital funding in the broad sense.

The level of organization efficiency of agrarian sector financial support is mainly determined by the effective state financial policy. In turn, the prudent state financial policy determines the success of subsequent economic transformations in the agricultural sector, creating conditions for attracting foreign and domestic sources of financing. In the conditions of deepening the market and structural reorganization of the agricultural sector financial resources formation and use in agricultural enterprises are affected by a variety of factors, primarily which include:

- seasonality of production and demand for agricultural products, and the related volume fluctuations of cash flow and solvency of enterprises;

- dependence of the enterprises operation results and sources of funding from the influence of climatic conditions;

- adverse weather conditions, environmental degradation, especially for plant growing and related processing industries;

- the main means of agricultural production is land, which is not amortized, and therefore does not participate in the formation of the cost of production. At the same time, different levels of land natural fertility and location contributes to the formation differentiated income (rents) of producers;

- significant specificity of this sector is self-reproduction. A significant part of the resulting products are not sold, and remains for the enterprise in the form of young stock, feed, fertilizers for the fields. Therefore, it is not included in the commodity production and does not take the form of money, but it is involved in on-farm turnover.

- state regulation of agricultural market, in particular by restricting or establishing a certain level of prices and tariffs, adoption of new standards for food, etc.

These factors lead to specific forms of this sphere entities finance organization. Due to these specifics, the market mechanisms of management in agriculture cannot be implemented with the same completeness and efficiency in other sectors. Therefore, agricultural food production requires the use of specific mechanisms of financial support, which is a system of financing sources and forms of agricultural production development and expanded reproduction. It manifests itself in five forms: self-financing (internal self-financing), lending, financing from the budget (state support), equity financing and mixed risk financing (innovation funds) (Sokolska, 2014). According to A. R. Zhydyak, searching the ways to improve the model of rational organizational economic mechanism of agricultural enterprises financial support one should take into account different principles: decentralization, compactness, intensity, reducing intermediate links, dialectical interaction between self-regulation and state regulation, flexibility, openness, adequate social-economic situation, etc. (Zhydyak, 2013). Further development of agriculture requires financial resources. Demand of the agricultural producers has been already formed, as in the fierce market competition; the progressive entities left, technology vendors require significant financial investments (Levchenko, 2008).

Based on the above, the mechanism of financial support for agribusiness sustainable development in the region must include: measures of fiscal, credit, tax support and insurance coverage of agricultural producers. It should be promotional in nature and directed at support of 
agricultural industries susceptibility to the development of production innovation and formation of civilized market relations. It must also include the use of subsidies for purchase and introduction of modern technology and scientific and technical products; reduction in the tax base of land tax with the amount of own funds, which will be spent on improving soil fertility, expansion and development of cleaner production; financing of capital investments in the development of science, technology and innovation projects, etc. Problems of effective management of the agrarian sector enterprises activity financial support requires a constant search for the optimal forms, methods and tools that meet the needs of the enterprises themselves, the priorities of the economic policy and the formation of the prerequisites for economic growth.

\section{Conclusion}

In the article it is concretized the content of such concepts as «financial support» and «mechanism of financial support». It was found that the main directions of improving the effectiveness of the financial mechanism of the agricultural sector of Ukraine's economy is the creation of a favorable environment for opening and maintaining the agricultural business and ensuring effective public financial support for its development at the beginning of activities. The consequences of the financial mechanism effective implementation are achieving a strong consumer, investment, innovation, institutional and social effects in rural areas.

Current economic conditions need the implementation of new requirements for the creation of a favorable business environment and adequate methods of its regulation. Dynamic transformation as a necessary prerequisite for the development of national economy, the objective transformational changes in the structure of its branches in favor of further qualitative development of the agrarian sector of Ukraine's economy require functioning of the mechanisms, functional load of which is an account of positive influence of external and internal factors, preventing the negative impact of hazards or threats of continuity of the subjects of financial relations activity and stimulation the efficiency of their management with describing the strategic priorities of sustainable growth through the implementation of new innovative approaches, measures and methods of formation and use of financial resources. At the same time, thanks to the development and operation of the financial mechanism it becomes possible to support the full development of agriculture. Thanks to it, it is provided balancing of cash flows in favor of expanded reproduction based on the successful combination of the laws of the market economy and state regulation of its development. It helps to avoid distortions and imbalances in the distribution and redistribution of financial resources in agriculture.

However, the process of raising funds in the agricultural sector of Ukraine has been significantly slowed down with the influence of political and economic crises of recent years. As a result inflationary pressures intensified, investment potential of the state budget decreased, the financial condition of agricultural enterprises has worsened the outflow of bank deposits is increased, number of lossmaking financial institutions is increased, the volume of bank lending to businesses was reduced, investment activity of foreign investors decreased. The deceleration of this process in Ukraine was caused by corruption in the government, powerful tax burden and an imperfect legal framework, especially in the sphere of protection of owners and investors e rights.

\section{References}

Andriichuk, V.H. (2004). The economy of agricultural enterprises. - Kyiv, KNEU, 624 p.

Babich, A.M., Pavlova, L.N. (1999). State and municipal finances. - Moscow, Finansy, JuNITI, 687 p.

Barulin, S.V. (2010). Finance. - Moscow, KNORUS, 640 p.

Bodi, Zv., Merton R.K. (2013). Finance. - Moscow, Publishing House “Williams”, 2013.

Bolshakov, S.V. (2006). Finance companies. Theory and practice. - Moscow: Book World, 2006. - 617 p.

Dikan, L.V., Holub, Yu.O. (2007). Financial support for the enterprise: the nature and source. Economy Development, issue 3 (43), p. 65-68.

Goncharov, V.N., Ivanyuk, I.V. (2012). Financial engineering enterprises in Ukraine. EKONOMINFO, issue 18, p. 43-46.

Hutz, E.E. (2007). Provision of farm financial resources in a time of change and stabilization. Economy AIC, issue 3, p. 46-53.

Kardanskaya, N.L. (1999). Management decision-making. - Moscow, UNITY, 407 p.

Kuznetsov, S.A. (1998). Great Dictionary of the Russian language. - St. Petersburg, "Norint".

Levchenko, N.M. (2008). State support to the financial security of the agricultural sector, available at: http://www.kbuapa.kharkov.ua/e-book/db/2008-2/doc/2/03.pdf

Lupenko, Yu.O., Mesel-Veseliak, V.Ya. (2012). Strategic directions of development of agriculture of Ukraine till 2020. - Kyiv, NSC “IAE”, 182 p.

Oparin, V.N. (2001). Finance (general theory). - Kyiv, Kyiv National Economic University, 240 p.

Pavlova, L.N. (2003). Financial Management. - Moscow, UNITY-DANA, 269 p.

Rodionova, V.M. (1994). Finances. - Moscow, "Finance and Statistics”. 
Samsonov, N.F. (2001). Financial management. - Moscow, Finance, 495 p.

Shablovskaya, T.V. (2007). Financial support for retailers in rural areas: status and development strategy, Abstract. Minsk, 20 p.

Sokolska, T.V. (2014). Financial support for agriculture. Economy and management of agribusiness, issue 1, p. 140-146.

Stetsiuk, P.A. (2005). Formation of financial resources of agricultural enterprises. Economy AIC, issue 11, p. 111-116.

Zhydyak, O.R. (2013). The problem of improving the mechanism of funding businesses agricultural areas. BusinessInform, issue 2, p. 139-141.

Zyatkovskyy, I.V. (2000). The financial support of business - Ternopol, Economic thought, $215 \mathrm{p}$.

\section{Владимир МАЦКИВ}

\section{ЭКОНОМИЧЕСКАЯ СУЩНОСТЬ И СОСТАВЛЯЮЩИЕ ФИНАНСОВОГО ОБЕСПЕЧЕНИЯ АГРАРНОГО СЕКТОРА}

Аннотация. Целью исследования является научное обоснование теоретико-методических подходов к основным принципам функционирования существующей системы финансового обеспечения аграрного сектора Украины и потенциальных направлений ее совершенствования путем построения новых действенных механизмов развития финансирования. Методика. В исследовании использовались следующие методы: морфологический и компаративный - для раскрытия содержания и развития научной мысли в трактовке понятия «финансовое обеспечение»; систематизации и обобщения - для определения функционального назначения аграрного сектора, необходимости его финансового обеспечения и раскрытие особенностей его функционирования; системный - для построения модели реализации системы финансового обеспечения развития аграрного сектора; логический - для последовательного обобщения теоретических и практических положений научного исследования. Результаты. Исследование становления и развития учения о финансовом обеспечении и систематизация научной мысли относительно его сути, дали возможность рассмотреть содержание исследуемой категории с точки зрения функционального подхода. Трактовка финансовое обеспечение сводится к тому, что формирование теоретических основ сущности и экономической природы финансового обеспечения является результатом достижений ученых не одного поколения, каждый из которых вложил свой весомый вклад в развитие теории изучаемого понятия. Это позволило провести анализ трактовки дефиниции «финансовое обеспечение» и обобщение сложившихся подходов через призму деятельности аграрного сектора. С точки зрения функционального назначения установлено, что финансовое обеспечение, как явление, можно рассматривать в контексте его уникальной значимости в развитии экономики. Практическое значение. Определено, что проблемы финансового обеспечения развития аграрного сектора в Украине свидетельствуют комплексный характер и касаются экономической, социальной и политической сфер их функционирования. Важнейшими препятствиями в финансово-кредитной сфере были и остаются: отсутствие должной финансовой инфраструктуры содействия ее развитию; недостаток имущества, которое может быть принято как достаточно ликвидный залог для обеспечения гарантий возврата кредита; сложная процедура получения банковского кредита и продолжительность принятия решений о предоставлении льготных кредитов; неосведомлённость и отсутствие единых правил доступа субъектов хозяйствования к источникам финансовых ресурсов; регулярная потребность в средствах для пополнения оборотных средств; потребность в финансовых ресурсах для функционирования и тому подобное. Конкретизировано и улучшено содержание понятия «финансовое обеспечение» как системы, для которой характерна совокупность элементов (инструменты, формы, методы финансирования, рычаги финансового влияния) и взаимосвязь между ними, надлежащая организация которой должна быть направлена на эффективное развитие аграрного сектора, выполнение возложенных на него функций и способность отображать тесноту взаимосвязи между всеми структурными элементами системы в процессе обеспечения аграрного бизнеса финансовыми ресурсами. Значение/оригинальность. Такая трактовка содержательной сущности позволяет осуществить обоснование средств финансового обеспечения развития аграрного сектора Украины. 